\title{
Commercially-Prepared Allograft Material Has Biological Activity In Vitro
}

Yoichiro Shigeyama, ${ }^{*}$ John A. D'Errico, ${ }^{*}$ Roger Stone, ${ }^{\dagger}$ and M.J. Somerman ${ }^{*}$

THE WELL-ESTABLISHED FINDING that implantation of demineralized bone matrix at non-skeletal sites results in formation of cartilage and bone has been attributed to bone morphogenetic proteins/factors. Commercially-available demineralized bone allograft materials are being used currently to reconstruct/regenerate bone. The studies described here focused on establishing biological activity of protein extracts prepared from commercially obtained bone graft material in vitro. Furthermore, the biological activity of these protein extracts in vitro was compared with similar extracts prepared from freshly obtained human bone. Biological activities of bone matrix proteins examined included their ability to promote proliferation, attachment, and migration of gingival fibroblasts using an in vitro system. Guanidine followed by guanidine/EDTA was used to separate bone matrix proteins into proteins associated with soft tissues of bone and proteins retained within the mineral compartment, respectively. Two preparations of each starting material were tested and the biological activity of each preparation was evaluated in triplicate at least three times. Slot blot analysis revealed that commercially-prepared material contained type I collagen; fibronectin; BSP; and BMP-2, 4, and 7. However, the freshly prepared bone extracts appeared to have higher BMP concentrations. The ability of commercial extracts to promote cell proliferation, while significant, was limited and significantly less when compared with similar extracts prepared from freshly obtained bone. All extracts promoted cell attachment significantly, while none of the extracts promoted cell migration. Thus, commercially-prepared material retained proteins having the capacity to influence cell behavior in vivo. However, some biological activity as measured in vitro was lost as a result of tissue processing. J Periodontol 1995;66:478-487.

Key Words: Cartilage; grafts, bone; bone matrix; bone regeneration; protein extract.

Studies as early as 1923 provided evidence that autogenous bone grafts could be used successfully to restore bone lost as a consequence of periodontal disease. ${ }^{1}$ This resulted in increased emphasis on evaluating different types of bone graft materials, as well as other materials including resorbable and nonresorbable membranes, for their capacity to restore periodontal tissues (see reference 2 for review). The knowledge that demineralized bone matrix powder (DMBP)/demineralized freeze-dried bone allograft material (DFDBA) was capable of inducing mesenchymal cells to differentiate into osteoblasts in vivo ${ }^{3}$ resulted in attempts to use DFDBA, obtained from human

*Department of Periodontics/Prevention/Geriatrics, University of Michigan, Ann Arbor, MI.

'Biotechnology Department, Corporate Research Division, MVL, Procter and Gamble, Cincinnati, $\mathrm{OH}$.

‡Depàrtment of Pharmacology, University of Michigan, Ann Arbor, MI. cadavers, in periodontal defects. Results from these studies indicated that DFDBA had the capacity to promote regeneration of the periodontium. ${ }^{2}$ The strong evidence that factors/proteins present in bone played a role in regulating the development, maintenance, and regeneration of mineralized tissues prompted several laboratories to identify and characterize specific proteins from bone (see references 4 to 6 for review).

Initial studies by Urist ${ }^{3}$ and Reddi and Huggins ${ }^{7}$ helped to clarify the events occurring during induction of mineralization by DFDBA in vitro and in vivo. Such studies, along with subsequent work, established that factors/proteins present in DFDBA stimulate 1) migration and attachment of cells at the healing site; 2) proliferation of cells; 3) biosynthetic activity by cells; and 4) chondroblastic and osteoblastic cell differentiation.89 Advanced technologies enabled researchers ${ }^{10,11}$ to identify further a 
family of proteins having osteogenic activity. To date nine bone morphogenetic proteins (BMPs) have been cloned and sequenced: BMP-1, BMP-2 (formerly BMP-2A), BMP-3 (also called osteogenin), BMP-4 (formerly BMP2B), BMP-5, BMP-6 (human homologue of the murine Vgr-1), BMP-7 (also called osteogenic protein-1 or OP1), BMP-8 (OP-2), and BMP-9.11,12 Except for BMP-1, BMPs are members of the transforming growth factor- $\beta$ (TGR- $\beta$ ) superfamily. TGF- $\beta$ s are found in high concentration in bone, as well as in platelets ${ }^{13}$ and have wide ranging effects on cell proliferation, differentiation, and organization. In bone, proposed roles for TGF- $\beta$ s include as coupling factors, which regulate the transition from bone resorption to bone formation, ${ }^{13,14}$ and as differentiation factors regulating control over dẻvelopment and regeneration of mineralized tissues..$^{15-17}$

In addition to BMPs, many other proteins associated with mineralized tissues have been implicated as playing a role in the regulation of these tissues. The most predominant protein of bone is collagen. The major collagen of bone is type I, with a small amount of other types, including types III and V. ${ }^{18}$ Noncollagenous matrix proteins associated with bone include osteocalcin (bone 'gla' protein), matrix 'gla' protein, osteonectin, osteopontin (OPN), bone sialoprotein (BSP), bone acidic glycoprotein-75 (BAG-75), thrombospondin, proteoglycans (decorin, biglycan), and serum proteins (albumin, $\alpha$ 2-HS-glycoprotein). In addition, fibronectin and tenascin, which are present on the periosteal and endosteal surfaces of bone, were isolated from the extracellular matrix (ECM) of bone. ${ }^{19}$

We have sought to further characterize proteins associated with ECM of bone and other mineralized tissues; e.g., cementum and dentin, and reported that protein extracts of mineralized tissues included proteins which enhanced attachment, ${ }^{20,21}$ protein production, ${ }^{22}$ and chemotactic activity of periodontal cells and gingival fibroblasts in vitro. ${ }^{23.24}$ The studies described here focused on establishing biological activity of protein extracts prepared from commercially-obtained bone graft material. Furthermore, we were interested in determining whether these protein extracts possessed the same activity as that of protein extracts prepared from freshly obtained human bone. This is an important question since commercial materials are processed differently than materials used in the laboratory ${ }^{25}$ and commercial materials are being used currently to reconstruct/regenerate bone.

Biological activities of protein extracts examined included their ability to promote proliferation, attachment, and migration of cells using an in vitro system. We found that commercially-prepared material contained type I collagen, fibronectin, BSP, BMP-2, BMP-4, and BMP-7 and stimulated cell attachment. However, the ability of these extracts to promote cell proliferation was limited when compared with similar extracts prepared from freshly obtained bone. None of the extracts studied promoted cell migration.

\section{MATERIALS AND METHODS}

\section{Bone Extractions}

In order to characterize and compare the biological activities of fresh human bone chips and commercially-purchased bone powder (DFDBA), both original materials were further processed in exactly the same fashion and proteins extracted as described previously ${ }^{25}$ and outlined in Figure 1A and 1B. Procedures for use of human bone were approved by the School of Dentistry Committee to Review Grants for Clinical Research and were in compliance with state and federal laws. Proximal tibias were obtained from a 76-year-old-female and bone was cleansed of adherent soft tissue and shattered under liquid nitrogen. The bone fragments were washed to remove marrow and blood contamination with phosphate buffered saline (PBS), $\mathrm{pH} 7.4$, containing protease inhibitors (0.05M 6-aminohexanoic acid, $0.005 \mathrm{M}$ benzamidine $\mathrm{HCl}$ and $0.001 \mathrm{M}$ phenylmethylsufonyl fluoride) for 2 days at $4^{\circ} \mathrm{C}$. Bone matrix proteins were sequentially extracted with $4 \mathrm{M}$ guanidine- $\mathrm{HCl}$ followed by $4 \mathrm{M}$ guanidine- $\mathrm{HCl} /$ EDTA at $4^{\circ} \mathrm{C}$, each for 7 days. These extracts were first gravity filtered through Whatman No. 1 filters, and then concentrated by ultra filtration under pressure through Amicon YM-10 filters. Concentrated extracts were dialyzed against distilled water and lyophilized. Lyophilized samples were stored at $-20^{\circ} \mathrm{C}$ until use. The guanidine$\mathrm{HCl}$ and guanidine- $\mathrm{HCl} / \mathrm{EDTA}$ extracts represented $0.03 \%$ and $0.01 \%$ of the starting material by weight, respectively. For example, our extractions started with approximately $100 \mathrm{~g}$ of bone, which yielded a dry weight of $30 \mathrm{mg}$ and $10 \mathrm{mg}$ for the guanidine- $\mathrm{HCl}$ and guanidine-HCl/EDTA extracts, respectively.

Commercially-prepared demineralized bone powder used for periodontal regenerative therapy was obtained from the American Red Cross (irradiated cortical demineralized bone powder, 300 to $500 \mu \mathrm{m}$ particle size). This material undergoes a variety of treatments at the American Red Cross prior to shipping, as shown in Figure 1B. Before removal of the bone tissue, the donor was exposed to a low dose (1.0 to 1.5 megarads) of gamma irradiation. Bones were cleansed of soft tissue, washed in distilled sterile water to remove lipids, marrow, and blood and soaked in an antibiotic solution containing polymixin- $\beta$, vasotracin-B and gentomycin for 1 hour. Next, the bone was milled to 300 to $500 \mu \mathrm{m}$ particle size, soaked in $70 \%$ ethanol, and demineralized in $0.6 \mathrm{~N} \mathrm{HCl}$ for approximately 1 hour. Then the demineralized powder was rinsed with water until $\mathrm{pH} 7.0$ was achieved, followed by a $70 \%$ ethanol wash, lyophilized, and packaged under vacuum.

For purposes of this study, this material was then subjected to $4 \mathrm{M}$ guanidine- $\mathrm{HCl}$ followed by $4 \mathrm{M}$ guanidine- $\mathrm{HCl} / \mathrm{EDTA}$ at $4^{\circ} \mathrm{C}$, each for 7 days, filtered through Whatman No. 1 filters, concentrated by ultra filtration through Amicon YM10 filters, dialyzed and lyophilized, as described above for 


\section{A. EXTRACTION FROM FRESH HUMAN BONE}

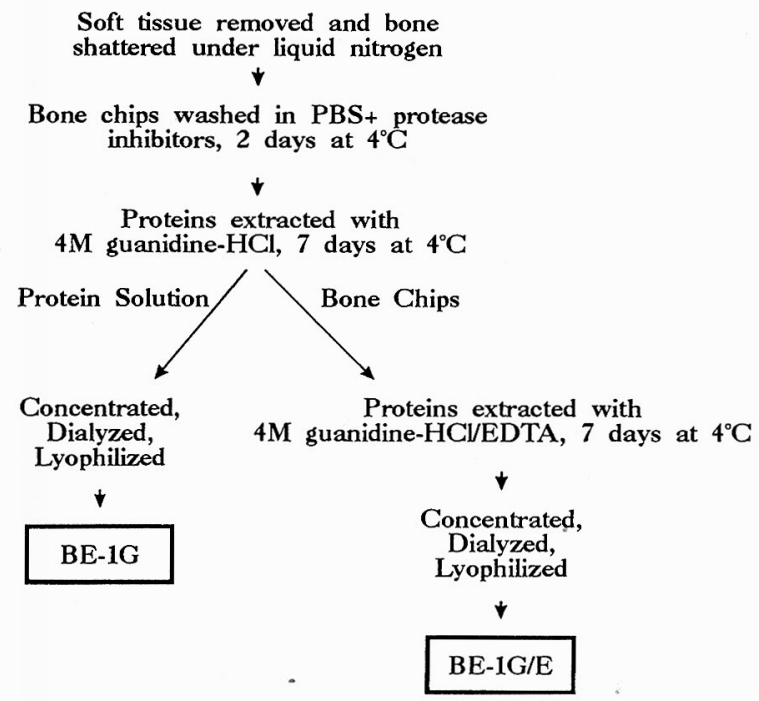

\section{B. EXTRACTION FROM DFDBA}

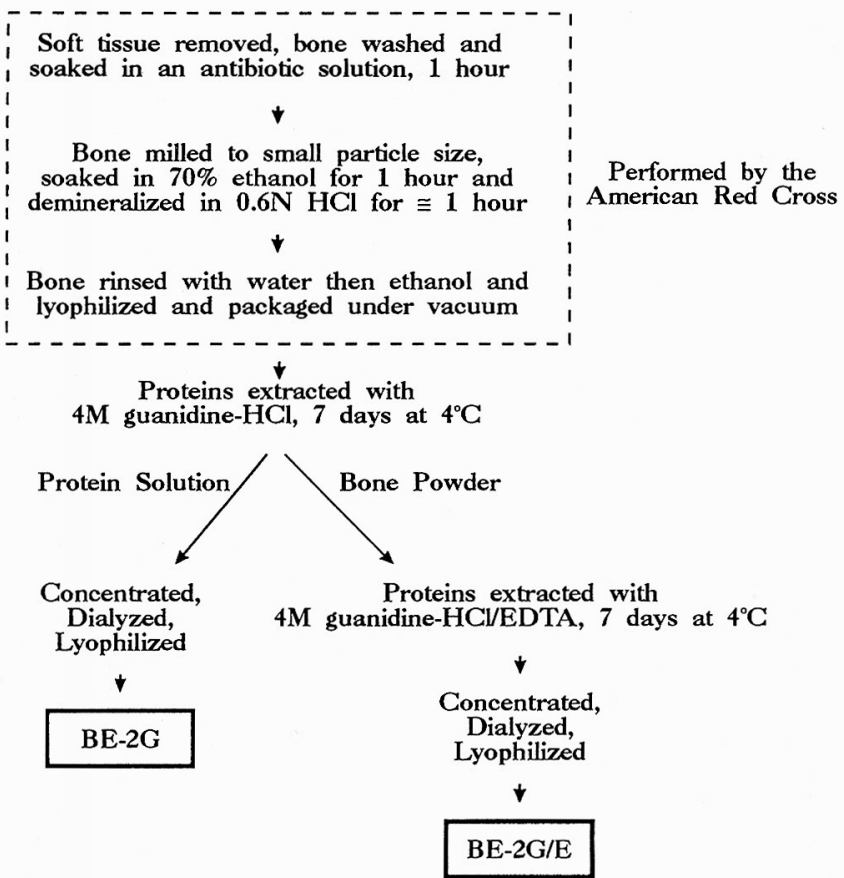

Figure 1. Schematic diagram of the procedure used for isolating proteins from bone. The main difference between the extractions was the procedure used to prepare the bone prior to extraction of proteins. The fresh human bone (A) was shattered under liquid nitrogen and the bone chips were washed in phosphate buffered saline with protease inhibitors. The DFDBA (B) was washed in water containing antibiotics, soaked in $70 \%$ ethanol and demineralized in $0.6 \mathrm{~N} \mathrm{HCl}$ prior to shipping.

fresh bone. The guanidine- $\mathrm{HCl}$ and guanidine- $\mathrm{HCl} / \mathrm{EDTA}$ extracts represented $1.0 \%$ and $0.4 \%$ of the starting material by weight, respectively. For example, our extractions started with approximately $10 \mathrm{~g}$ of DFDBA, which yielded a dry weight of $100 \mathrm{mg}$ and $40 \mathrm{mg}$ for the guanidine- $\mathrm{HCl}$ and guanidine$\mathrm{HCI} / \mathrm{EDTA}$ extracts, respectively.
Throughout this paper, bone matrix proteins from the proximal tibia are referred to as $\mathrm{BE}$ (bone extract) $1 \mathrm{G}$ and $\mathrm{BE}-1 \mathrm{G} / \mathrm{E}$, for the guanidine- $\mathrm{HCl}$ and guanidine- $\mathrm{HCl} /$ EDTA extracts, respectively, and similar extracts obtained from commercially-prepared demineralized bone powder are referred to as BE-2G and $\mathrm{BE}-2 \mathrm{G} / \mathrm{E}$, respectively. It is important to note that the commercially-prepared bone was partially demineralized using $0.6 \mathrm{~N} \mathrm{HCl}$, soaked in an antibiotic solution and $70 \%$ ethanol, and lyophilized prior to shipping. Other differences between the two procedures included the rinsing of fresh bone with PBS plus protease inhibitors versus rinsing commercial bone with distilled water without protease inhibitors.

\section{Cells}

Human gingival fibroblasts and periodontal ligament cells, cultured from healthy tissue explants obtained from premolars extracted for orthodontic reasons, were used in these studies. Cells were grown in Dulbecco's modified Eagle's medium (DMEM), 10\% fetal bovine serum (FBS), and antibiotics and used between the fourth to twelfth passage, as described previously. ${ }^{26}$ Initially our studies were conducted with both human gingival fibroblasts and periodontal ligament cells. We noted no differences between the effects of extracts on gingival fibroblasts compared with their effects on periodontal ligament cells and therefore, reported here are results with gingival fibroblasts.

\section{Attachment Assay}

The assay used to determine the ability of the bone extracts to promote attachment of gingival fibroblasts was a modification of the Klebe method. ${ }^{27}$ Uncoated 24-well bacteriological plates were precoated with $400 \mu \mathrm{l}$ of the putative attachment agent at a concentration of 5,25 , or $50 \mu \mathrm{g} / \mathrm{ml}$ in water. Agents included a positive control (fibronectin) $\mathrm{FN} ; \$$ a negative control (wells coated with water); and BE-1G, BE-1G/E, BE-2G, and BE-2G/E. After the coatings had dried, dishes were preincubated for 1 hour at $37^{\circ} \mathrm{C}$ in $400 \mu \mathrm{l}$ DMEM containing $1 \mathrm{mg} / \mathrm{ml}$ bovine serum albumin (BSA). After the preincubation period, $2 \times 10^{4}$ cells in $100 \mu l$ DMEM/BSA were added to each of the wells and incubated for an additional 1.5 hours. Following incubation, photographs of the attached and unattached cells were taken using a phase contrast microscopell and wells were rinsed with $500 \mu \mathrm{l}$ Hanks' balanced salt solution (HBSS)"I to remove unattached cells. Remaining cells were removed enzymatically and counted by Coulter counter. All agents were evaluated in triplicate.

\footnotetext{
sChemicon, Temecula, CA.

"Axiovert 35, Zeiss, Thornwood, NY.

Gibco-BRL, Grand Island, NY.
} 


\section{Proliferation Assay}

Proliferation assays were conducted to determine the ability of the bone matrix extracts to affect proliferation of gingival fibroblasts. Gingival fibroblasts at approximately $80 \%$ confluency were removed from flasks with $0.08 \%$ trypsin and $0.04 \%$ EDTA, washed with DMEM containing $10 \% \mathrm{FBS}$, and resuspended to a concentration of $1 \times$ $10^{4}$ cells $/ \mathrm{ml}$. One $\mathrm{ml}$ of the cell suspension was added to each experimental well of a 24 well tissue culture treated plate and incubated overnight at $37^{\circ} \mathrm{C}$ with $5 \% \mathrm{CO}_{2}$ to allow cells to attach. The following day, designated day 0 , the medium was replaced with one $\mathrm{ml}$ of either DMEM with $10 \%$ FBS (positive control), DMEM with $2 \%$ FBS (negative control), or DMEM with $2 \%$ FBS plus bone matrix extracts. The bone matrix extracts, BE-1G, BE$1 \mathrm{G} / \mathrm{E}, \mathrm{BE}-2 \mathrm{G}$, and BE-2G/E, were assayed at 25 and 50 $\mu \mathrm{g} / \mathrm{ml}$. To establish the number of cells present on day 0 ; i.e., prior to addition of agents, cells in each of three wells were processed for counting by Coulter counter. Experimental agents were added on day 0 and cells harvested on day 2 , day 5 , and day 10 by removing media and rinsing cells two times with HBSS. Adherent cells were detached with trypsin/EDTA and counted by Coulter counter. All agents, at each time point, were evaluated in triplicate.

\section{Chemotaxis Assay}

The ability of the four bone matrix extracts to act as chemoattractants for gingival fibroblasts was determined using a modified Boyden chamber assay. ${ }^{28}$ Polycarbonate membranes, $8 \mu \mathrm{m}$ pore size ${ }^{\#}$ were precoated with $20 \mathrm{mg}$ porcine skin gelatin** in $1000 \mathrm{ml}$ water for 60 minutes at $90^{\circ} \mathrm{C}$ and allowed to dry overnight. For chemotaxis assay, $34 \mu$ l of test agent was placed in the lower chamber of a Boyden chamber. Bone extracts were evaluated at 0 , $2,5,10,25$, and $100 \mu \mathrm{g} / \mathrm{ml}$ concentration diluted with DMEM and $0.1 \%$ BSA. In addition, fibronectin at concentrations of 10 and $25 \mu \mathrm{g} / \mathrm{ml}$, served as a positive control. The lower chamber was covered with the gelatin coated membrane, and the upper chamber was screwed into place. The upper chamber was filled with $200 \mu$ of the cells suspension containing $1.5 \times 10^{4}$ cells in DMEM and $0.1 \% \mathrm{BSA}$, and incubated for 4 hours at $37^{\circ} \mathrm{C}$. Following the incubation period, the membranes were carefully removed, cells adhering to the upper surface of the membrane dislodged, and cells on the lower surface fixed in methanol for 30 seconds. Cells were stained ${ }^{\dagger \dagger}$ and membranes placed on glass slides. To determine cell migration, individual cells within five fields, at $200 \times$ magnification, were counted per membrane. ${ }^{23,24.28}$

\footnotetext{
"Costar 150414, Cambridge, MA.

**Sigma Chemical Co., St. Louis, MO.

Hemacolor, Diagnostic Systems Inc., Gibbstown, NJ.
}

\section{Gel Electrophoresis}

For gel electrophoresis, samples (reduced with 5\% 2-mercaptoethanol) were analyzed by 4 to $20 \%$ gradient SDSPAGE with a $4 \%$ stacking gel, according to the method of Laemmli. ${ }^{29}$ Molecular weight standards were used. Following electrophoresis, gels were stained with silver nitrate following the procedure described by Schoenle et al. ${ }^{30}$ Two hundred (200) $\mu \mathrm{g}$ of the guanidine-HCl/EDTA extracts $(\mathrm{BE}-1 \mathrm{G} / \mathrm{E}$ and $\mathrm{BE}-2 \mathrm{G} / \mathrm{E})$ were loaded on the gels, while $100 \mu \mathrm{g}$ of the guanidine extracts $(\mathrm{BE}-1 \mathrm{G}$ and $\mathrm{BE}$ $2 \mathrm{G}$ ) were loaded. Initially $200 \mu \mathrm{g}$ of BE-1G and BE-2G were used, but BE-1G stained too darkly, and band resolution was not possible; thus the lower amount was used for both guanidine extracts in order to achieve appropriate comparisons between samples.

\section{Western Blot}

For immunological staining of specific proteins in the bone extracts, slot blot analysis was performed as described. ${ }^{31}$ Briefly, $200 \mu \mathrm{g}$ of protein samples in $200 \mu \mathrm{l}$ tris-buffered saline (TBS, $10 \mathrm{mM}$ Trizma-base, $\mathrm{pH} 7.4$ and $0.9 \% \mathrm{NaCl}$ ) were applied to Westran membranes with the aid of a BioRad slot blotter apparatus. Pre-immune sera controls were routinely run. Nonspecific hybridization was prevented by placing the membranes in TBS containing 3\% BSA for 60 minutes at room temperature. The membranes were then rinsed twice in TBST (TBS with $0.05 \%$ Tween 20 )** and placed in TBS-T containing $3 \%$ BSA and the appropriate primary antibody for 1 hour at room temperature. All antibodies were raised in rabbits against human proteins (fibronectin, BSP and type I collagen) or synthetic peptides derived from the human protein sequences (BMPs) and final dilutions were as follows: fibronectin, 1:500, type I collagen, 1:500,\$ BSP, 1:500 (LF-6, a gift from Dr. Larry Fisher, NIH/ NIDR); ${ }^{32,33}$ and BMP-2, 1:50; BMP-4, 1:100; and BMP7, 1:100 (gifts from Beth Koenig, Procter and Gamble Co., Cincinnati, $\mathrm{OH}$ ). BSP was used for several reasons, including the specificity of this protein for mineralized tissues, ${ }^{21,34,35}$ the adhesive properties of this protein ${ }^{36}$ and the potential for this protein to function as a nucleator of hydroxyapatite. ${ }^{35,37}$ The membranes were then washed twice in TBS-T and incubated in TBS-T with 3\% BSA and goat anti-rabbit IgG ( $\mathrm{H}$ and $\mathrm{L}$ ) labeled with horseradish peroxidase conjugate blot grade ${ }^{\mathrm{I}}$ at a concentration of 1:1000 for 1 hour at room temperature. The membranes were washed again twice in TBS-T, rinsed quickly with TBS containing 5\% methanol, and protein bands were visualized by soaking the membrane in TBS with 4-chloro-1-naphthol until background color appeared. The developing reaction was stopped by rinsing in TBS and 5\% methanol, and the membranes were photographed.

Schleicher \& Schuell, Keene, NH.

$\$$ Biodesign International, Kennebunkport, ME. 


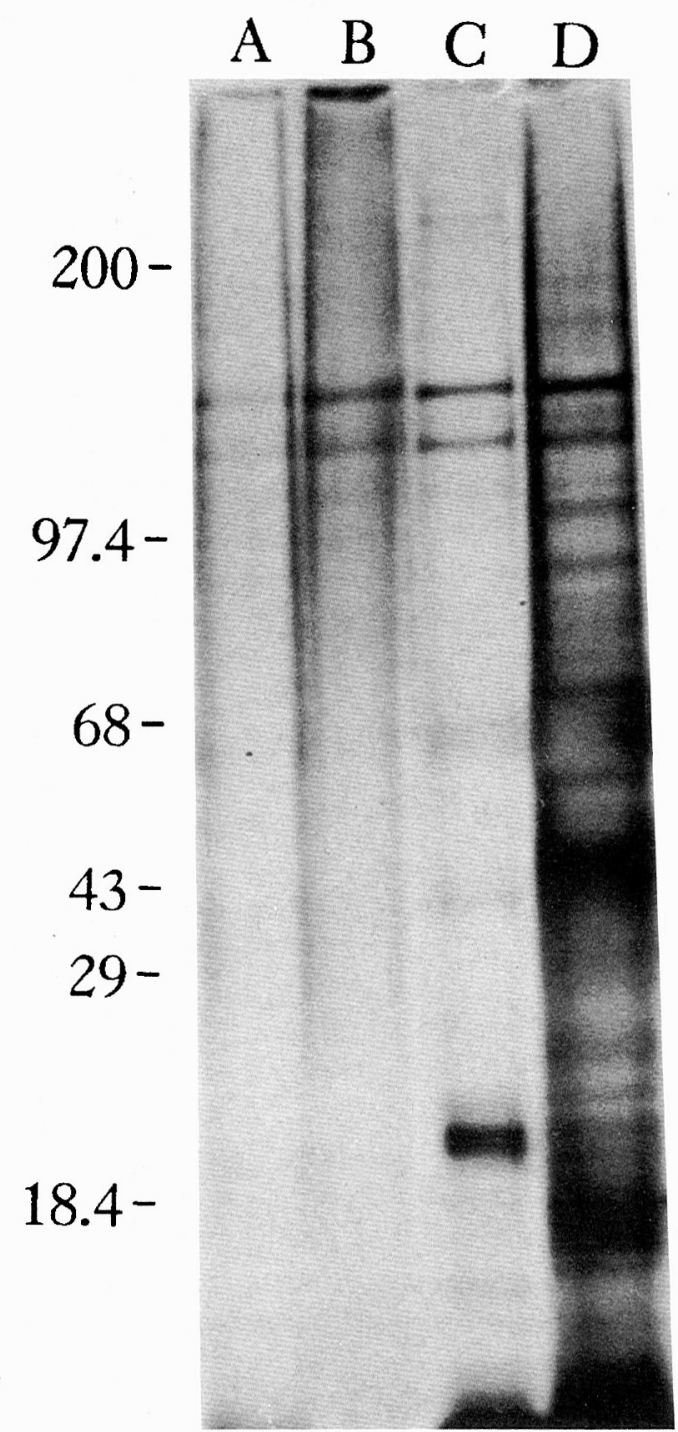

Figure 2. SDS-PAGE of protein extracts from human bone. One hundred $\mu \mathrm{g}$ of the guanidine- $\mathrm{HCl}$ extracts and $200 \mu \mathrm{g}$ of the guanidine- $\mathrm{HCl} /$ EDTA extracts were loaded on a reducing 4 to $20 \%$ gradient polyacrylamide gel with a $4 \%$ stacking gel and stained with silver nitrate. Protein extracts from the commercially prepared bone, $B E-2 G$ and $B E-2 G / E$, are in lanes $A$ and $B$, respectively. Extracts prepared from fresh human bone, $B E-I G / E$ and $B E-I G$, are in lanes $C$ and $D$, respectively.

\section{Statistical Analysis}

Significant differences in bone extract activity was determined by ANOVA and Tukey-Kramer multiple comparisons test using Instat computer software. All experiments were repeated at least 3 times. The data are represented as mean \pm standard deviation and significance $(P \leq$ 0.05 ) is denoted by an asterisk.

\section{RESULTS}

After extraction of the proximal tibia and DFDBA, as described above, the composition of proteins from these extracts were examined by SDS-PAGE (Fig. 2). BE-1, both $G$ and $G / E$, had more intense banding throughout when compared with $\mathrm{BE}-2$, both $\mathrm{G}$ and $\mathrm{G} / \mathrm{E}$. Examination of the composition of all extracts demonstrated distinct bands in the high molecular region, suggestive of type I collagen. BE-1G, BE-1G/E, and BE-2G/E also presented weakly stainable bands in the 200,000 dalton region suggestive of fibronectin (Fig. 2, lanes D, C, and B, respectively). BE-1G gel profile depicted a number of components below 98,000 daltons (Fig. 2, lane D). Also, in BE$1 \mathrm{G} / \mathrm{E}$, light but distinct bands were observed around $68,000,43,000$, and 16,000 daltons (Fig. 2, lane C). In addition, intense and distinct bands were also observed in the lower molecular region around 20,000 daltons in the BE-1G/E (Fig. 2, lane C). This contrasted with limited banding observed in this region with all other extracts (Fig. 2, lanes A, B, and D).

To further characterize the nature of the bands depicted by SDS-PAGE, slot blot analysis was used. We were particularly interested in determining whether these extracts contained any bone morphogenetic proteins (BMPs). In addition, to assure that our extraction procedure was adequate and that our slot blot system was sensitive, we determined whether these extracts contained type I collagen, fibronectin and BSP. Figure 3 shows the results of these studies. Slot blot analysis for BE-1 indicated that fibronectin, BMP-2, BMP-4, BMP-7, and type I collagen were present in both $\mathrm{BE}-1 \mathrm{G}$ and $\mathrm{BE}-1 \mathrm{G} / \mathrm{E}$. In contrast, $\mathrm{BSP}$ antibody responded positively to $\mathrm{BE}-1 \mathrm{G} / \mathrm{E}$ with no response to $\mathrm{BE}-1 \mathrm{G}$. Analysis of $\mathrm{BE}-2$ extracts, BE-2G and $B E-2 G / E$, indicated the presence of BSP, BMP-2, and type I collagen, although the positive reaction of BMP-2 antibody was slight. Fibronectin, BMP-4, and BMP-7 antibodies responded positively only to $\mathrm{BE}-2 \mathrm{G} / \mathrm{E}$.

As shown in Figures 4A and $4 \mathrm{~B}$, respectively, BE-1G and $\mathrm{BE}-1 \mathrm{G} / \mathrm{E}$ had a significant effect on promotion of cell proliferation of cultured human gingival fibroblasts at concentrations of 25 and $50 \mu \mathrm{g} / \mathrm{ml}$. BE-2G significantly promoted proliferation of cells at a concentration of 50 $\mu \mathrm{g} / \mathrm{ml}$ (Fig. 4A). In contrast, BE-2G/E did not stimulate proliferation of cells at concentrations of 25 and $50 \mu \mathrm{g} /$ ml (Fig. 4B).

In addition to proliferative activity, attachment and chemotactic properties of these extracts were investigated. All extracts significantly enhanced attachment of human gingival fibroblasts, in vitro (Figs. 5A and B). Fibronectin, which was served as positive control, yielded similar effects. The effects of protein extracts on spreading of cells are demonstrated in Figure 6. Cells exposed to fibronectin, the positive control, and all protein extracts, exhibited a spindle-shaped appearance, indicative of a functional response to the extracts, while unattached (negative control) cells had a circular appearance. In contrast to the positive effects of these extracts on cell adhesion, none of the extracts promoted migration of cells, as analyzed by Boyden chamber method, at concentrations of 2 to $100 \mu \mathrm{g} / \mathrm{ml}(P<0.05)$. Fibronectin, the positive con- 


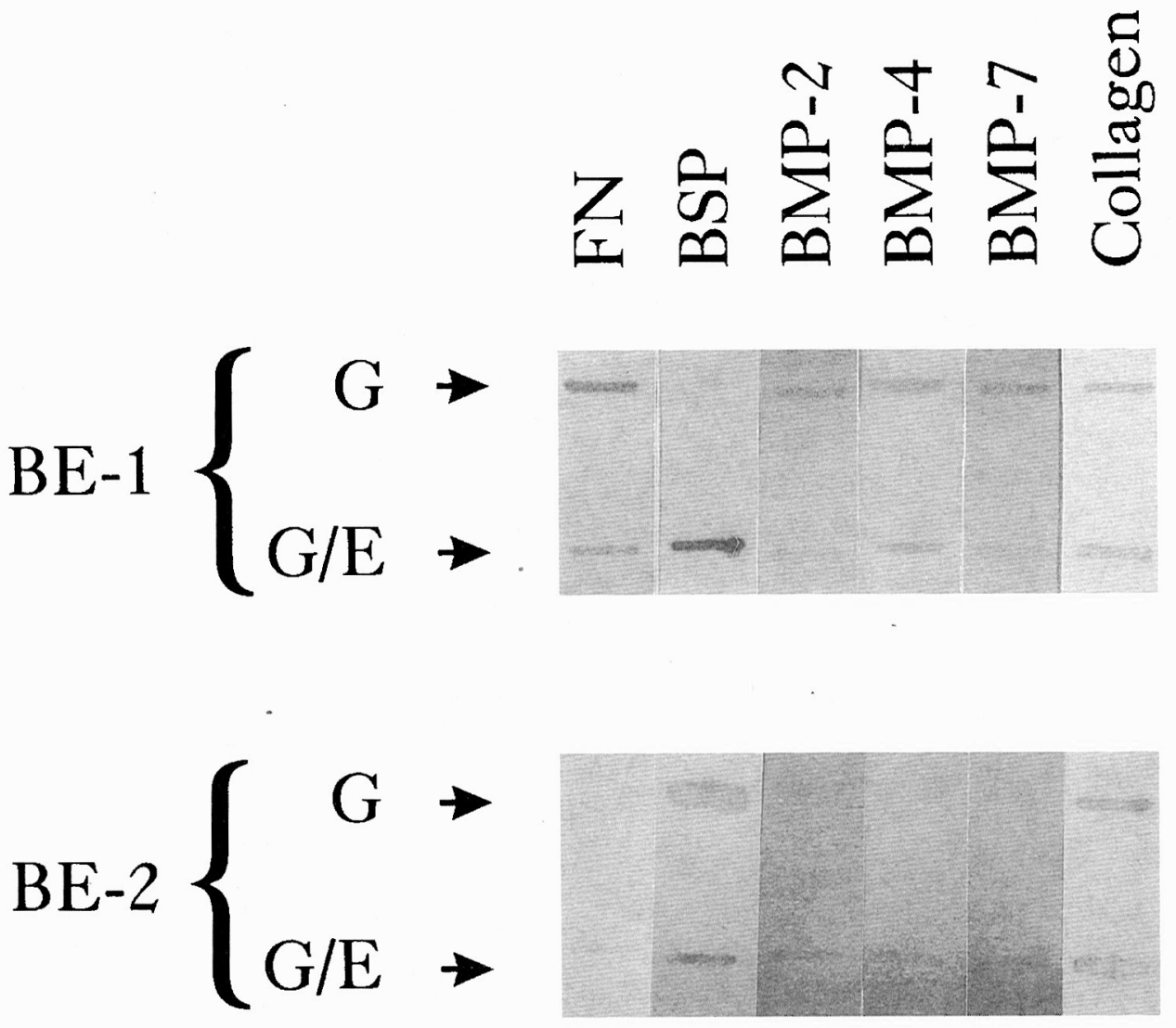

Figure 3. Slot blot analysis of bone extracts. Two hundred $\mu \mathrm{g}$ of protein samples were applied to Westran membranes and tested for the presence of fibronectin $(F N)$, bone sialoprotein $(B S P)$, bone morphogenetic proteins 2, 4 and 7 and type I collagen. All antibodies used were raised in rabbit against human proteins or peptides and visualized by staining with $\operatorname{IgG}(H$ and $L)$ labeled with horseradish peroxidase.

trol used for the chemotaxis assay, promoted migration at concentrations of 10 and $20 \mu \mathrm{g} / \mathrm{ml}$ (data not shown).

\section{DISCUSSION}

As summarized in Table 1, these studies demonstrate that commercially-prepared demineralized bone powder (DFDBA) retains proteins with biological capacity as evaluated in vitro. When compared with protein extracts prepared from fresh bone (BE-1), they exhibit a similar ability to stimulate cell attachment. Furthermore, they retain BMPs known to have chondrogenic/osteogenic potential. However, BMPs appear to be present at a lower concentration in BE-2, and in addition, BE-2 preparations have less ability to promote cell proliferation when compared with BE-1 preparations.

We used procedures similar to those described by Termine et al. ${ }^{25}$ for extraction of bone matrix proteins: $4 \mathrm{M}$ guanidine- $\mathrm{HCl}$ followed by $4 \mathrm{M}$ guanidine- $\mathrm{HCl} / 0.5 \mathrm{M}$ EDTA, which separates bone matrix proteins into proteins associated with soft tissues of bone and mineral compartment noncollagenous proteins, including serum-derived proteins which are absorbed to crystal surfaces, respectively. It is not surprising to find mineral-associated proteins such as BMPs retained in DFDBA. The well- established finding that subcutaneous or intramuscular implantation of demineralized bone matrix at non-skeletal sites of rodents results in formation of cartilage and bone has been attributed to bone morphogenetic proteins/factors for decades. ${ }^{3,7}$

The results presented here indicate that freshly obtained human bone contains the BMPs (BMPs 2, 4, and 7) assayed, and that these BMPs can be extracted from the matrix with guanidine- $\mathrm{HCl}$, with further removal with guanidine-HCl/EDTA. These findings suggest that both the nonmineral-associated compartment of bone, including cells, blood, and adhering connective tissues and the mineral-associated compartment of bone, contain BMPs. This result is supported by the studies of Lianjia et al. ${ }^{38}$ where, using immunohistochemistry, they demonstrated BMPs in fibrous connective tissue surrounding the bone matrix in calcifying fibrous epulis. The examination of BMPs from commercially prepared bone, as determined by slot blot analysis, indicated the presence of BMPs 2 , 4 , and 7 in the BE-2G/E, with little response to BMPs antibodies in BE-2G. One explanation for the relative lack of BMPs in BE-2G is that some proteins were removed during the commercial processing of this bone by $\mathrm{HCl}$ 

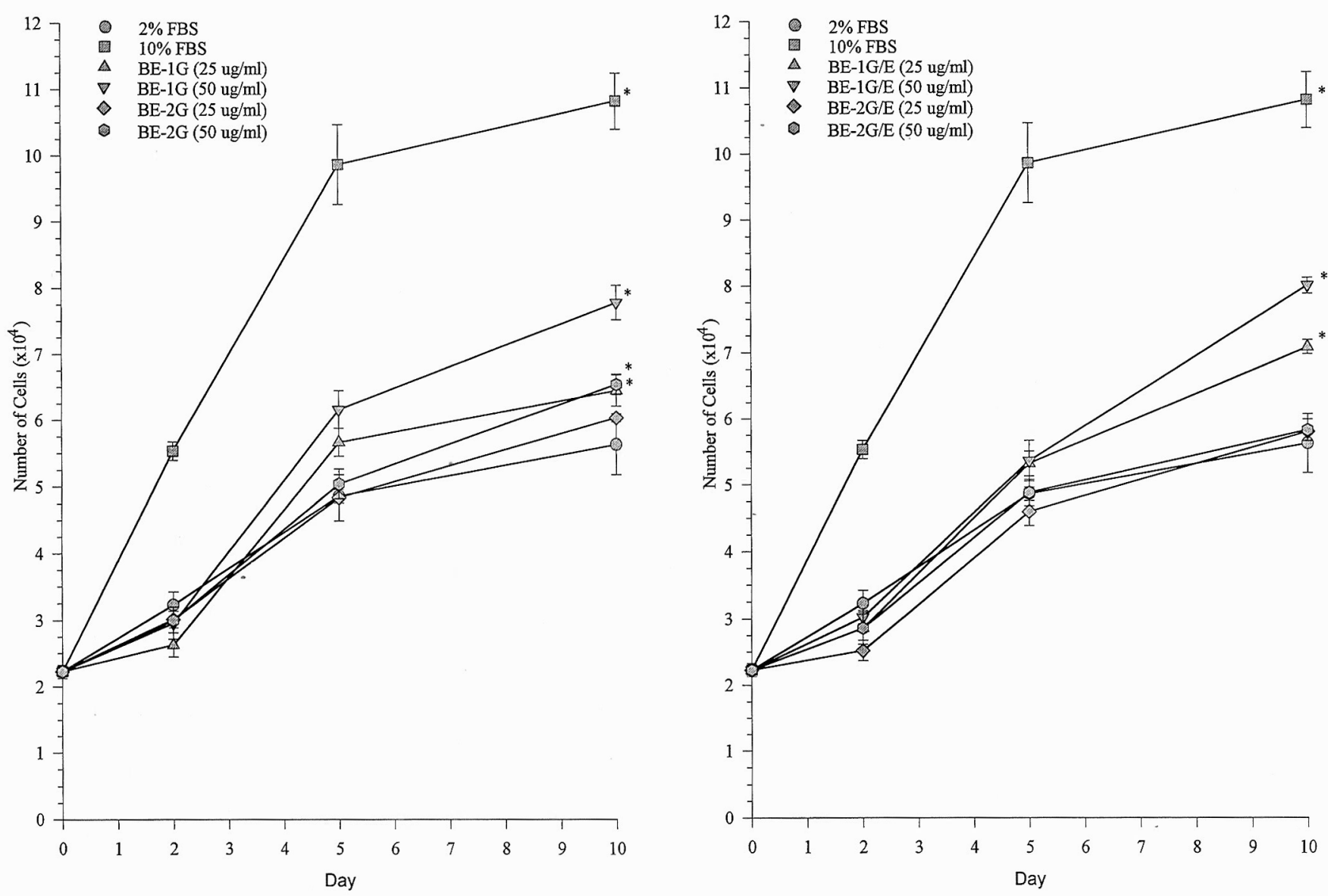

Figure 4. Effects of bone extracts on proliferation of human gingival fibroblasts. Bone extracts, guanidine-HCl (A) and guanidine-HCl/EDTA (B), were tested for their effect on proliferation of gingival fibroblasts. Extracts were tested at 25 and $50 \mu \mathrm{g} / \mathrm{ml}$ in DMEM containing $2 \%$ FBS. DMEM containing $2 \%$ FBS represents a negative control, and as a positive control DMEM containing 10\% FBS was used. All agents were evaluated in triplicate. Data expressed as total number of cells \pm standard deviation ( $* P<0.05)$.

(Fig. 1). In contrast, other investigations ${ }^{39,40}$ reported extraction of osteoinductive proteins from bone matrix by guanidine- $\mathrm{HCl}$, after acid demineralization. The discrepancy between our lack of BMPs in BE-2G and these other studies may be explained by several factors including differences in the method used for processing of demineralized bone powder, the tissue type selected and/or the age of the patient from whom bone was obtained. It is interesting that BMPs were extracted easily from fresh human bone (BE-1) without EDTA-demineralization. This finding may help to explain, at least in part, past clinical studies where non-demineralized freeze-dried bone allografts have been shown to have regenerative activity. ${ }^{41.42}$

Slot blot analysis also revealed the presence of BSP in all extracts except BE-1G. These results support the localization of BSP to mineral-associated compartments of mineralized tissues..$^{21,34,35}$ The presence of BSP in BE-2G is probably due to the prior demineralization with $\mathrm{HCl}$ during commercial processing. BSP is an adhesion protein selective to mineralized tissue, with affinity for type I collagen ${ }^{43}$ and believed to play a regulatory role in biomineralization. ${ }^{35,37,44}$ In addition, type I collagen was present in all four extracts. Interestingly, Paralkar et al. ${ }^{45}$ reported that BMP-3 (osteogenin) binds to types I and IV collagen. The osteoinductive activity of BMPs has been shown to be promoted by reconstitution with their associated collagenous matrices, predominantly type I collagen ${ }^{46,47}$ Thus, interactions between BSP/BMPs and collagenous substratum are most certainly important for bone induction.

Commercially prepared bone retained biological activity, as measured by the assays used here. All four protein extracts examined enhanced attachment of cultured human gingival fibroblasts. Fibronectin (positive control) alone, a universal adhesion protein and chemoattractant, enhanced attachment and chemotactic activity of cells in this study. Electrophoresis and slot blot analyses showed that fibronectin was present in all extracts except BE-2G, but most likely at a concentration less than $5 \mu \mathrm{g} / \mathrm{ml}$ of extract. Therefore the ability of these extracts to promote cell attachment cannot be attributed totally to fibronectin content or BSP content, indicating that other molecules may be important for promoting cell attachment. 

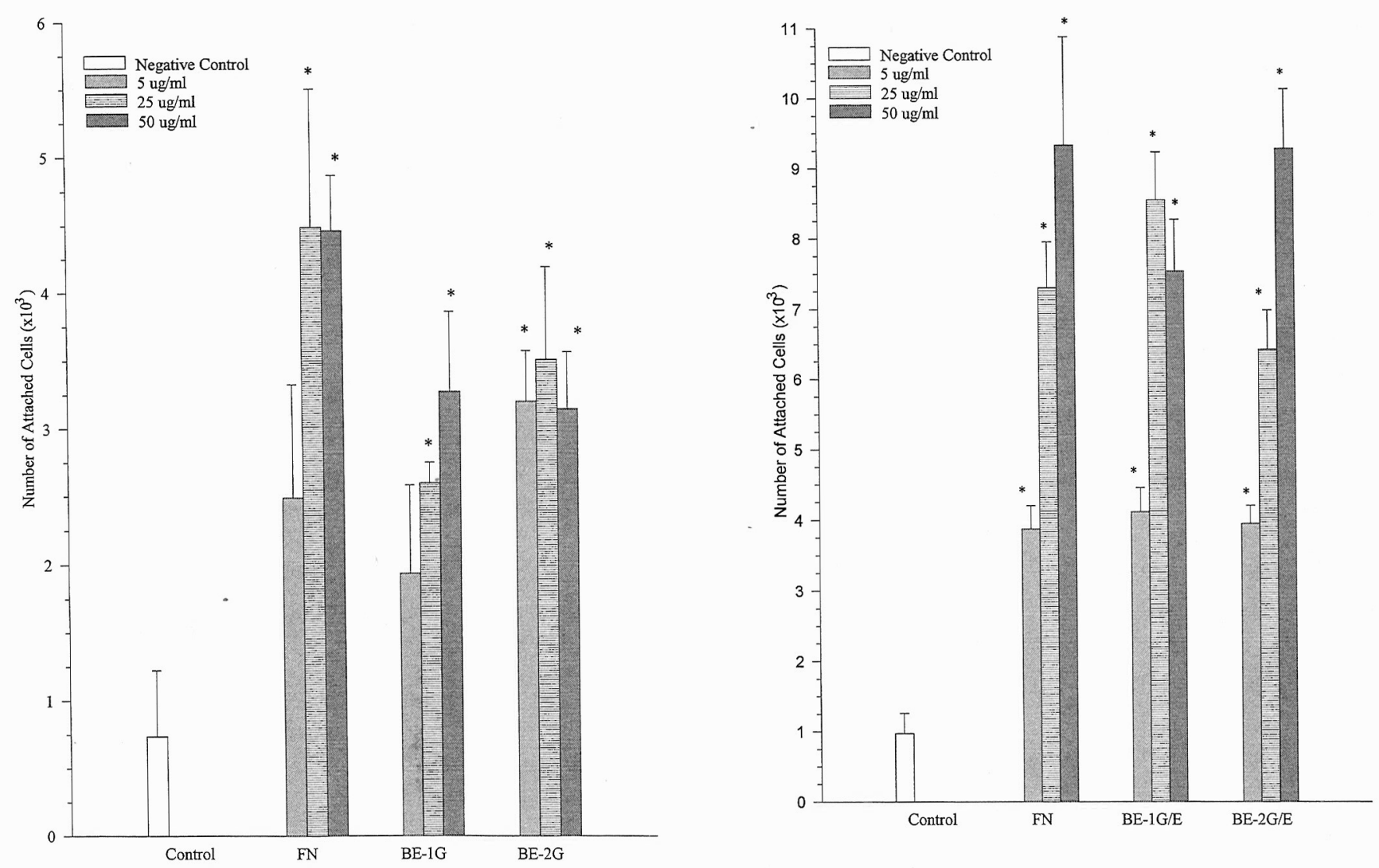

Figure 5. Effects of bone extracts on attachment of gingival fibroblasts. Dishes were dry coated with fibronectin (a positive control), BE-1G, BE-1G/ E, $B E-2 G$, or $B E-2 G / E$ at a concentration of 5,25 , or $50 \mu \mathrm{g} / \mathrm{ml}$ in water; wells coated with water acted as a negative control. Wells were preincubated with DMEM containing BSA $(1 \mathrm{mg} / \mathrm{ml})$ for 1 hour prior to the addition of cells. Cells $\left(2 \times 10^{4}\right.$ cells/well $)$ were allowed to attach for 1.5 hour and attached cells quantitated by Coulter counter. All agents were evaluated in triplicate. Data expressed as total number of attached cells \pm standard deviation $(* P<0.05)$.

Next the chemotactic activity of the extracts was determined, but none of these extracts promoted cell migration. This is in agreement with our previous studies indicating that extracts of older adult human bone failed to enhance cell migration. ${ }^{24}$ In contrast, protein extracts of rat, bovine, and fetal human bone, as well as cementum extracts, enhanced migration of various cells of mesenchymal origin. ${ }^{23,24,48-50}$ Even though some of these studies were not conducted with gingival fibroblasts, cells of mesenchymal origin have been shown previously to respond in a similar manner. ${ }^{26}$ The results from the present study support our previous finding. Younger bone may have a higher concentration of chemotactic factors than older bone. While highly speculative at this point, we propose that addition of chemotactic factors selected for osteoblast-like cells to DFDBA would be valuable to improve the regenerative capacity of DFDBA.

Proliferation studies indicated that BE- $1 \mathrm{G}$ and $\mathrm{BE}-1 \mathrm{G} /$ $E$ had a significant effect on stimulatory cell proliferation at concentrations of 25 and $50 \mu \mathrm{g} / \mathrm{ml}$. In contrast, of the BE-2 extracts, only the BE- $2 \mathrm{G}$ extract, at a concentration of $50 \mu \mathrm{g} / \mathrm{ml}$, stimulated cell proliferation. This finding supports those of Hauschka et al. ${ }^{51}$ They reported that acid extraction with $\mathrm{HCl}$ followed by an extraction with guanidine- $\mathrm{HCl}$ reduces bone-derived growth factor yield as compared with guanidine- $\mathrm{HCl}$ extraction alone. Hence, it is possible that factors which promote cell proliferation are removed or altered during the processing of DFDBA. However, as discussed above, we found higher concentrations of BMPs 2,4 , and 7 in BE-2G/E, relative to BE$2 \mathrm{G}$. Recent studies demonstrated that osteoinductive proteins, such as BMPs, enhanced osteoblast differentiation, but not cell proliferation. ${ }^{5,47.52 .53}$ In contrast, other researchers reported that BMPs stimulate proliferation of fibroblasts ${ }^{54}$ and osteoblasts. ${ }^{55.56}$ It is generally accepted, depending on conditions in vitro, that BMPs may promote, inhibit, or have no effect on cell proliferation. Thus, it is conceivable that DFDBA may enhance cell attachment and/or differentiation, rather than proliferation, and that the proliferative activity found in BE-1 is not associated with the presence of BMPs.

In summary, we describe biological activity of protein extracts of bone in vitro. These studies are the first, to our knowledge, to analyze the biological properties of DFDBA in vitro. Commercially-prepared material retained proteins that have the capacity to influence cell 


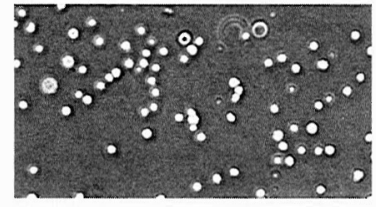

$\mathrm{CN}$

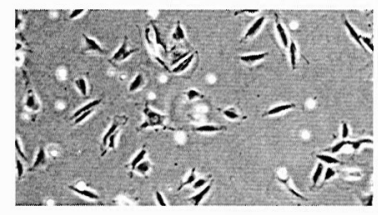

BE-1G

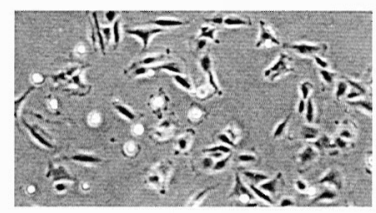

$\mathrm{BE}-1 \mathrm{G}_{i} \mathrm{E}$

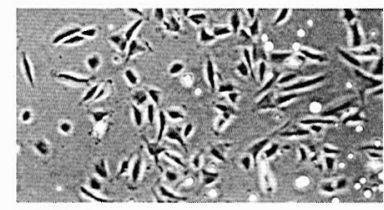

FN

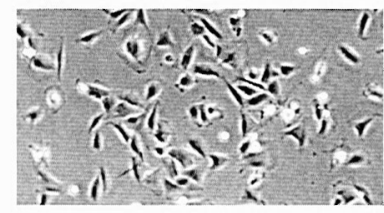

BE-2G

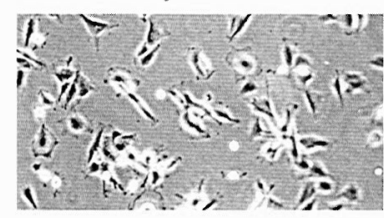

$\mathrm{BE}-2 \mathrm{G}_{i} \mathrm{E}$
Figure 6. Photographic representation of protein extracts ability to promote cell attachment and spreading. Cells were allowed to adhere to plates for 2 hours and were photographed prior to removal of cells for counting by Coulter counter. Abbreviations; $\mathrm{CN}-$ water control (note rounded morphology with no cell attachment), FN-fibronectin control.

Table 1. Summary of Composition and Activity Associated with BE-1 and BE-2

\begin{tabular}{|c|c|c|c|c|}
\hline \multirow[b]{2}{*}{ Proteins/Activity } & \multicolumn{2}{|c|}{$\mathrm{BE}-1$} & \multicolumn{2}{|c|}{ BE-2 } \\
\hline & $\mathrm{G}^{*}$ & $\mathrm{G} / \mathrm{E}$ & G & G/E \\
\hline BMP-2 & ++ & ++ & + & ++ \\
\hline BMP-4 & ++ & ++ & - & ++ \\
\hline BMP-7 & ++ & ++ & - & ++ \\
\hline BSP & - & +++ & +++ & $++t$ \\
\hline Fibronectin & +++ & +++ & - & + \\
\hline Type I collagen & $+t+$ & $++t$ & +++ & +++ \\
\hline Proliferation & ++ & ++ & + & - \\
\hline Attachment & +++ & +++ & +++ & +++ \\
\hline Chemotaxis & - & - & - & - \\
\hline
\end{tabular}

differentiation and, thus possibly regeneration of tissues, in vivo. However, some regenerative capacity may be lost as a result of tissue processing. It is interesting to note that the concentration of proteins required to demonstrate biological activity in vitro, 25 to $50 \mu \mathrm{g} / \mathrm{ml}$, were less than those typically used to treat periodontal defects. The amount of extracted protein in both the BE-2G and BE$2 \mathrm{G} / \mathrm{E}$ combined represented about $1.5 \%$ of the total starting material. Clinically, a typical defect is treated with approximately $50 \mathrm{mg}$ of DFDBA. If only $1.5 \%$ of protein was released from this material, $750 \mu \mathrm{g}$ of protein would be available in the local environment.
Additional studies are required in order to establish which proteins/factors are responsible for the osteoinductive activity of demineralized bone.

\section{Acknowledgments}

The authors would like to thank Raymond Grant and Beth Koenig for antibodies against BMP peptides and critical review of this manuscript. The authors would also like to thank Christopher Strayhorn for technical assistance and Steven Rassi and Hetty Pate for preparation of this manuscript. This work was supported in part by Procter and Gamble, Cincinnati, $\mathrm{OH}$ and by NIDR/NIH grant DE09532.

\section{REFERENCES}

1. Hegduis $Z$. The rebuilding of the alveolar processes by bone translation. Dent Cosmos 1923;65:736-742.

2. Brunsvold MA, Mellonig JT. Bone grafts and periodontal regeneration. Periodontol 2000 1993;1:80-91.

3. Urist MR. Bone formation by autoinduction. Science 1965;150:893899.

4. Mariotti A. The extracellular matrix of the periodontium: Dynamic and interactive tissues. Periodontol 2000 1993;1:39-63.

5. Stanford C, Keller J. The concept of osseointegration and bone matrix expression. Crit Rev Oral Biol Med 1991;2:83-101.

6. Young M, Kerr J, Ibaraki K, Heegaard A, Robey P. Structure, expression, and regulation of the major noncollagenous matrix proteins of bone. Clin Orthop 1992;281:275-294.

7. Reddi AH, Huggins C. Biochemical sequences in the transformation of normal fibroblasts in adolescent rats. Proc Natl Acad Sci (USA) 1972;69:1601-1605.

8. Reddi AH. Regulation of local differentiation of cartilage and bone by extracellular matrix: A cascade type mechanism. Prog Clin Biol Res 1982;110:261-268.

9. Ripamonti U, Reddi AH. Growth and morphogenetic factors in bone induction: Role of osteogenin and related bone morphogenetic proteins in craniofacial and periodontal bone repair. Crit Rev Oral Biol Med 1992;3:1-14.

10. Celeste AJ, Iannazzi JA, Taylor RC, et al. Identification of transforming growth factor $\beta$ family members present in bone-inductive protein purified from bovine bone. Proc Natl Acad Sci (USA) 1990;87:9843-9847.

11. Wozney JM, Rosen V, Celeste AJ, et al. Novel regulators of bone formation: Molecular clones and activities. Science 1988;242:15281534.

12. Kingsley DM. The TGF- $\beta$ superfamily: New members, new receptors, and new genetic tests of function in different organisms. Genes Dev 1994;8:133-146.

13. Bonewald LF, Mundy GR. Role of transforming growth factor- $\beta$ in bone remodeling. Clin Orthop 1990;250:261-276.

14. Centrella M, Massague J, Canalis E. Human platelet-derived transforming growth factor- $\beta$ stimulates parameters of bone growth in fetal rat calvariae. Endocrinology 1986;119:2306-2312.

15. Vainio S, Karavanova I, Jowett A, Thesleff I. Identification of BMP4 as a signal mediating secondary induction between epithelial and mesenchymal tissues during early tooth development. Cell 1993;75: $45-58$.

16. Rosen V, Thies RS. Skeletal formation and the bone morphogenetic proteins. In: Tsang RC, Lemons JA, Balistreri WF, eds. Growth Factors in Perinatal Development. New York: Raven Press, Ltd; 1993:3.

17. Bennet NT, Schultz GS. Growth factors and wound healing: Biochemical properties of growth factors and their receptors. Am J Surg 1993;165:728-737. 
18. Hauschka PV, Wians FH. Osteocalcin-hydroxyapatite interaction in the extracellular organic matrix of bone. Anat Rec 1989;224:180 188.

19. Lukinmaa PL, Mackie EJ, Thesleff I. Immunohistochemical localization of the matrix glycoproteins-tenascin and the ED-sequencecontaining form of cellular fibronectin in human permanent teeth and periodontal ligament. J Dent Res 1991;70:19-26.

20. Somerman MJ, Perez-Mera M, Merkhofer RM, Foster RA. In vitro evaluation of extracts of mineralized tissues for their application in attachment of fibrous tissue. J Periodontol 1987;58:349-351.

21. Somerman MJ, Sauk JJ, Foster RA, Norris K, Dickerson K, Argraves WS. Cell attachment activity of cementum: bone sialoprotein II identified in cementum. J Periodont Res 1991;26:10-16.

22. Somerman MJ, Archer SY, Shteyer A, Foster RA. Protein production by human gingival fibroblasts is enhanced by guanidine EDTA extracts of cementum. J Periodont Res 1987;22:75-77.

23. Somerman M, Hewitt AT, Varner HH, Schiffmann E, Termine J, Reddi AH. Identification of a bone matrix-derived chemotactic factor. Calcif Tissue Int 1983;35:481-485.

24. Somerman MJ, Hotchkiss RN, Bowers MR, Termine J. Comparison of fetal and adult human bone: Identification of a chemotactic factor in fetal bone. Metab Bone Dis Relat Res 1983;5:75-79.

25. Termine JD, Belcourt AB, Conn KM, Kleinman HK. Mineral and collagen-binding proteins of fetal calf bone. J Biol Chem 1981;256: 10403-10408.

26. Somerman MJ, Archer SY, Imm GR, Foster RA. A comparative study of human periodontal ligament cells and gingival fibroblasts in vitro. $J$ Dent Res 1988;67:66-70.

27. Klebe R. Isolation of a collagen-dependent cell attachment factor. Nature 1974;250:248-251.

28. Postlethwaite AE, Snyderman R, Kang AH. Chemotactic attraction of human fibroblasts to a lymphocyte-derived factor. $J$ Exp Med 1976;144:1188-1203.

29. Laemmli UK. Cleavage of structural proteins during assembly of the head of bacteriophage T4. Nature 1970;227:680-685.

30. Schoenle EJ, Adams LD and Sammons DW. Insulin-induced rapid decrease of a major protein in fat cell plasma membranes. $J$ Biol Chem 1984;259:12112-12116.

31. Towbin H, Staehelin T, Gordon J. Electrophoretic transfer of proteins from polyacrylamide gels to nitrocellulose sheets: Procedure and some applications. Proc Natl Acad Sci (USA) 1979;76:4350 4354.

32. Fisher LW, Hawkins, Tuross N, Termine JD. Purification and partial characterization of small proteoglycans I and II, bone sialoprotein I and II and osteonectin from the mineral compartment of developing human bone. J Biol Chem 1987;262:9702-9708.

33. MacNeil RL, Sheng N, Strayhorn C, Fisher LW, Somerman MJ. Bone sialoprotein is localized to the root surface during cementogenesis. J Bone Min Res 1994;9:1597-1606.

34. Bianco P, Fisher LW, Young MF, Termine JD, Robey PG. Expression of bone sialoprotein (BSP) in developing human tissues. Calcif Tissue Int 1991;49:421-426.

35. Chen J, Sapiro HS, Sodek J. Developmental expression of bone sialoprotein mRNA in rat mineralized connective tissues. $J$ Bone Min Res 1992;8:987-997.

36. Somerman MJ, Fisher LW, Foster FA, Sauk JJ. Human bone sialoprotein I and II enhance fibroblast attachment, in vitro. Calcif Tissue Int 1988;43:50-53.

37. Hunter GK, Goldberg HA. Nucleation of hydroxyapatite by bone sialoprotein. Proc Natl Acad Sci (USA) 1993;90:8562-8565.

38. Lianjia Y, Yan J, Doi T, Sekine I, Ogawa K, Mori M. Immunohistochemical localization of bone morphogenetic protein (BMP) in calcifying fibrous epulis. J Oral Pathol Med 1993;22:406-410.

39. Sampath TK, Coughlin JE, Whetstone RM, et al. Bovine osteogenic protein is composed of dimers of OP-1 and BMP-2A, two members of the transforming growth factor- $\beta$ superfamily. $J$ Biol Chem 1990;265:13198-13205.

40. Wang EA, Rosen V, Cordes P, et al. Purification and characterization of other distinct bone-inducing factors. 1988; Proc Natl Acad Sci (USA) 1988;85:9484-9488.

41. Rummelhart JM, Mellonig JT, Gray JL, Towle HJ. A comparison of freeze-dried bone allograft and demineralized freeze-dried bone allograft in human periodontal osseous defects. $J$ Periodontol 1989;60:655-663.

42. Sepe WW, Bowers GM, Lawrence JJ, Friedlaender GE, Koch RW Clinical evaluation of freeze-dried bone allografts in periodontal osseous defects-part II. J Periodontol 1978;49:9-14.

43. Fujisawa R, Kuboki Y. Affinity of bone sialoprotein and several other bone and dentin acidic proteins to collagen fibrils. Calcif Tissue Int 1992;51:438-443.

44. Bianco P, Riminucci M, Silvestrini G, et al. Localization of bone sialoprotein (BSP) to golgi and post-golgi secretory structures in osteoblasts and to discrete sites in early bone matrix. $J$ Histochem Cytochem 1993;41:193-203.

45. Paralkar VM, Nandedkar AK, Pointer RH, Kleinman HK, Redd $\mathrm{AH}$. Interaction of osteogenin, a heparin binding bone morphogenetic protein, with type IV collagen. J Biol Chem 1990;265:1728117284.

46. Katz RW, Reddi AH. Dissociative extraction and partial purification of osteogenin, a bone inductive protein, from rat tooth matrix by heparin affinity chromatography. Biochem Biophys Res Commun 1988;157:1253-1257.

47. Kubler N, Urist MR. Allogenic bone and cartilage morphogenesis. Rat BMP in vivo and in vitro. $J$ Craniomaxillofac Surg 1991;19: 283-288.

48. Landesman R, Reddi AH. Chemotaxis of muscle-derived mesenchymal cells to bone-inductive proteins of rat. Calcif Tissue Int 1986;39: 259-262.

49. Lucas PA, Syftestad GT, Caplan AI. Partial isolation and characterization of a chemotactic factor from adult bovine bone for mesenchymal cells. Bone 1986;7:365-371.

50. Padley RA, Cobb CM, Killoy WJ, Newhouse NL, Boyan BD. In vitro chemotactic response of osteoblast-like osteosarcoma cells to a partially purified protein extract of demineralized bone matrix. $J$ Periodontol 1991;62:15-20.

51. Hauschka PV, Mavrakos AE, Iafrati MD, Doleman SE. Growth factors in bone matrix. Isolation of multiple types by affinity chromatography on heparin-sepharose. J Biol Chem 1986;261:1266512674.

52. Vukicevic S, Luyten FP, Reddi AH. Stimulation of the expression of osteogenic and chondrogenic phenotypes in vitro by osteogenin. Proc Natl Acad Sci (USA) 1989;86:8793-8797.

53. Niswander L, Martin GR. FGF-4 and BMP-2 have opposite effects on limb growth. Nature 1993;361:68-71.

54. Canalis E, Centrella M, Urist MR. Effect of partially purified bone morphogenetic protein on DNA synthesis and cell replication in calvarial and fibroblast cultures. Clin Orthop 1985;198:289-296.

55. Hiraki $\mathrm{Y}$, Inoue $\mathrm{H}$, Shigeno $\mathrm{C}$, et al. Bone morphogenetic proteins (BMP-2 and BMP-3) promote growth and expression of the differentiated phenotype of rabbit chondrocytes and osteoblastic MC3T3E1 cells in vitro. J Bone Min Res 1991;6:1373-1385.

56. Sampath TK, Maliakal JC, Hauschka PV, et al. Recombinant human osteogenic protein-1 (hOP-1) induces new bone formation in vivo with a specific activity comparable with natural bovine osteogenic protein and stimulates osteoblast proliferation and differentiation in vitro. J Biol Chem 1992;267:20352-20362.

Send reprint requests to: Dr. J.A. D'Errico, Department of Periodontics/Prevention/Geriatrics, University of Michigan School of Dentistry, Ann Arbor, MI 48109-1078.

Accepted for publication December 5, 1994 